\title{
Seed production of 'Grasslands Tama' Westerwolds ryegrass in practice
}

\author{
G. E. MOORE \\ Lynnford, R.D. 4., Ashburton
}

\begin{abstract}
A specialist management system for 'Grasslands Tama' Westerwolds ryegrass seed production is described. Planting, fertilizer, irrigation, harvesting and drying and machine-dressing policies are outlined. Particular emphasis is placed on the production of high seed-wcight crops.
\end{abstract}

Key words: Seed production. Lolium mulifllorum irrigation. sced harvesting, seed drying, seed dressing.

\section{INTRODUCTION}

Seed production of the new ryegrass cultivars is more likely to be successful if they are grown as a specialist crop with controlled management, rather than by the uncontrolled "catch crop" system which currently produces much of New Zealand's ryegrass seed. Farmers have often been disappointed in "catch crop" seed because, despite being of high grade certified origin and with good purity and germination, herbage production has often been below expectations.

A well-bred sheep with a proven genetic background cannot perform to its potential if management is poor, and exactly the same principles apply to plants. I am often surprised that farmers who spend so much time assessing the breeding and management of the stock which they purchase pay so little attention to cultivars and seed quality when buying seed. If this is the case, what should the prospective buyer look for? The seed should be well grown, plump and bright in colour, with a high seed weight ( $g / 1000$ seeds), good purity and germination, and from a certified line. Unfortunately, much ryegrass seed does not reach these standards. and in some cases, e.g., 'Grasslands Tama', factors like poor seed weight have seriously affected field performance and no doubt commercial usage (Brown, 1977).

In the remainder of this paper I will outline the results of 13 years' experience of growing Tama for seed production in a specialist system without grazing animals.

\section{PREPARATION OF SEEDBED}

Residues of the previous crop (e.g., wheat, barley, peas) are not burned, but preferably shredded or chopped and incorporated into the soil, using surface cultivation. In early April the area is ploughed and heavy-rolled. Subject to soil analysis, major element fertilizers such as lime may be applied. In late April or early May, shallow cultivation with discs and/or Dutch harrows is carried out to form a seedbed of "nobbly" texture of approximately $10 \mathrm{~cm}$ depth.

\section{PLANTING}

Breeders' or basic-grade seed is sown at a maximum rate of $30 \mathrm{~kg} / \mathrm{ha}$, in $15 \mathrm{~cm}$ drills at approximately $8 \mathrm{~cm}$ depth, and not rolled.

Unfortunately, there have been occasions when breeders' seed has had a low seed weight, thus increasing the population of low-vigour plants, and reducing subsequent seed production.

\section{FERTILIZER}

At planting, a broadcast application of N,P,K $12-10-10$, at $125 \mathrm{~kg} / \mathrm{ha}$, is incorporated into the soil by the action of drill coulters and covering harrows.

A follow-up application of N,P,K 12-10-10 at $370 \mathrm{~kg} / \mathrm{ha}$ is broadcast in late August or early September, prior to light rolling for surface consolidation.

The use of N,P,K type fertiliscr has been established in preference to other types or mixtures, primarily due to ease and accuracy of application. The use of potash and phos- 
phate in conjunction with nitrogen has indicated a greater reliability in obtaining the required seed weight. The granulated form of $\mathrm{N}, \mathrm{P}, \mathrm{K}$ presently used greatly reduces the risk of leaching of fertilizer elements from heavy rainfall and/or irrigation.

\section{IRRIGATION}

I feel we still have much to learn in this area, especially as to whether a "little and cften" is preferable to fewer but larger applications of water, in relation to growth patterns.

At the moment we prefer the former, and from the first sign of the "shoot-blade" emergence, soil moisture is regularly checked and water applied as and when required. A "travelling-gun" system is currently in use, in preference to "end-tow" or "side-roll", because of the minimal damage from wheel marks. No irrigation is applied during the pollination period, but we are always prepared to irrigate immediately after completion of the pollination process, and, if required, right through to the seed maturity stage.

\section{HARVESTING AND DRYING}

The best time to cut Tama is when shedding has commenced, with cutting operations at night and early morning, using $1.8 \mathrm{~m}$ sickletype mowers, as the swathe is usually far too bulky for windrowing. The natural drying of the mowed swathe is much more even and faster than that from windrows.

Threshing commences when the moisture content of the seed drops to about $25 \%$. The harvester takes two mower widths at a time, thus providing a much more even drop-flow, which causes little or no damage to the seed but allows removal of the awns.

The seed is immediately cooled by high volume air-flow within an "In-Bin" handling system. The drying process is attained with a minimum heat-rise of $5^{\circ} \mathrm{C}$ in high volume air. The maximum temperature should not exceed $37^{\circ} \mathrm{C}$, which may restrict heat addition depending on the mbient temperature. The seed must be cooled at the completion of the drying process.

\section{MACHINE DRESSING}

The drying bins we use have automatic unloading systems with direct bulk delivery to the dressing plant. All "first-grade" seed is processed to a minimum of $28 \mathrm{lb} / \mathrm{bu}$ weight standard (35 kg/hectolitre), and sacks packed to $50 \mathrm{~kg}$ net and sealed and tagged to Government certification requirements.

The machine dressing to these standards is readily achieved with heavier lines, thus enabling the product to be packed in standard $66 \mathrm{~cm}$ sacks (Chapman) without undue pres sure being applied. Pressing damage can often occur with light seed because of the excessive rubbing action of the press on the product.

\section{CONCLUSION}

Basically, all certified seeds require the Government certificate of proof of origin, purity and germination, which is the traditional guide for seed quality and valuation within the trade. However, I believe that seed weight and seed colour are very important. Herbage production is more reliable from plump, bright seed, and these important data should be included on P. \& G. certificates.

The pastoral farmer requires the maximum herbage production from the investment in seeds for pasture establishment.

The ryegrass seed producer surely is entitled to a premium monetary reward for producing the fundamental basis of all herbage production the seed.

Finally, despite our experience and technical knowledge. the best management advice services available, along with meteorological services, and so on these factors cannot forestall the main 'element of risk, perhaps the greatest worry to all ryegrass seed producers the weather. Very late frost, or cloudy or wet conditions during the pollination period, or a sudden hailstorm or severe windstorm at harvest time, can quickly spoil or even destroy the best looking ryegrass seed crop.

\section{REFERENCE}

Brown. K. R.. 1977. N.Z. I/ exp. Agric., 5: 143-6. 